Int. J. Speleol. 11 (1981), pp. 203-206

\title{
A Note on Directed Phytokarst in Sarawak (E. Malaysia).
}

\author{
Martin Laverty*
}

SUMMARY

A distinctive new type of phytokarst, oriented towards available light, has been found in cave entrances in the Gunong Mulu National Park, Sarawak, E. Malaysia. The kerst features of this area are spectacular and important.

Folk, Roberts and Moore (1973) noted an «unusually grotesque karst, characterised by jagged, spongy pinnacles of blacksurfaced limestone» at Hell, Grand Cayman, in the British West Indies. They distinguished this from ordinary karst because «plant filaments cover the whole surface, actively boring and dissolving their way into the rock and are not simply a surface coating; and the major distinctive morphological features- delicately spongy form and random orientation - are produced by boring plants, not through solution by rainwater which simply washes over the surface". They define this landform as phytokarst and restrict this to the attack of endolithic algal filaments on carbonate rocks, the algae dissolving their way into these in order to escape bright sunlight, to obtain metabolic carbon, or to obtain a damp tunnel to better hold capillary water. The authors do, however, envisage the process as being extendable to "other kinds of susceptible rocks" and to "other types of endolithic plants, such as fungi". Their opiniion was that phytokarst "probably occurs only in the more humid tropical climates" and that "important algal rock sculpture is either rare or has gone unrecognised in tropical karst». Chadha (1976) has since described similar phytokarst in Jammu Pro-

* School of geography, Oxford Univ. 
vince in N.W.India, where black-coated carbonate rocks present tne appearance of a "stony lacework . . resembling a spongex.

' 'his note gives a preliminary report of presumed phytokarst unserved in the Gunong Mulu National Park, Sarawak. The uccurrences described here differ from those of earlier reports in that the landform are highly oriented towards a light source and occur in cave entrances.

The Gunong Mulu National Park is situated at $114^{\circ} 55^{\prime} \mathrm{E}$, $4^{\circ} 05^{\prime} \mathrm{N}$, on the island of Borneo. The climate is humid tropical with some monsoonal influence; the temperature varies little from $27^{\circ} \mathrm{C}$, and the annual rainfall is about $5000 \mathrm{~mm}$ on the lowlands. Mulu Formation sandstones, shales and slates are uverlain by the pure, Eocene-Miocene Melinau Limestone Formation, which forms upstanding mountains and also underlies a karst marginal plain. Very extensive cave systems (over $100 \mathrm{~km}$ to 1983) have been discovered in these mountains and it is in the entrances to some of these caves that directed phytokarst has been observed. In particular, fine examples occur in the main entrance to Hijau Lobang (Green Cave), in the Skylight of Lobang Angin (Cave of the Winds), and in the main and skylight entrances to Gua Terangair (Clearwater Cave). Details of the caves are to be found in Brook and Waltham (1978), Eavis (1981); popular accounts of the geomorphology in Sweeting (1979), and of the caves in Waltham \& Brook (1979), and full details of all work carried out in the area will appear in the Sarawak Museum Journal (Kuching).

Waltham describes the directed phytokarst (first called photokarst by the speleological team which discovered it) thus: "photokarren consists of solutional slots inclined at around $45^{\circ}$ and all oriented towards the sunlight from the cave entrance which controls the plant growth on the rock" (Brook \& Waltham, 1978. At least two distinct morphological forms exist, however, which can be identified by focussing attention on the residual rock. The two forms resemble either a sheaf of rods of several millimetres uniform diameter up to $10 \mathrm{~cm}$ long, or an arrangement of jagged spearheads up to $1 / 2 \mathrm{~m}$ in length and $10 \mathrm{~cm}$ base diameter. The latter may vary between being bladed and being conical, sometimes having delicate bridges linking them to adjacent spears; in this characteristic they resemble the phytokarst illustrated by Folk et al.

The rock surface is light green in colour in contrast to the very dark or black colours observed by Folk et al. and Chadha. This is probably because of a different endolithic population to the coccoid blue green algae (Gloeocapsa alpina) identified at Hell. At Hijau Lobang, the major flora observed were thought to be blue-green algae (unidentified) as well as mosses (Verrucaria $s p$. ) and lichens (Pinnatella sp.). 
The phytokarst was observed both on bedrock and on boulders on which shafts of direct sunlight fell, always being oriented precisely towards the incident direction of the light. It may be significant that the Melinau Limestone in which the phytokarst has developed has been found to be one of the hardest limestones known, according to the Schmidt hammer tests carried out by M.J.Day (Sweeting, 1979). The phytokarst at Hell is also developed in very hard dolomites, and that of Jam$\mathrm{mu}$ in "highly dolomitised biolithites with an extreme degree of diagenesis».

\section{Further observations}

Chemical and hydrological observations show that the rate of iimestone corrosion in the area is very high - about $150 \mathrm{~m}^{3}$ $\mathrm{km}^{-2} \mathrm{yr}^{-1}$. This is supported by direct weight loss measurements on limestone tables exposed in different environments for a months. For example, $20 \mathrm{~g}$ cubes lost up to $10 \%$ of their mass when suspended in a river, 5\% when buried in soil, slightly less in leaf litter, and up to $2 \%$ when hung in the open air and subject only to rainfall. It is probably because of this that normal forms of surface karren dominate open-air outcrops: these can develop to spectacular proportions, as illustrated by the Pinnacles, limestone needles up to $50 \mathrm{~m}$ in height which cover substantial areas of the mountain terrain (R.G. Ley 1980), - Geographical Journal). Phytokarst may, however, prove to be more extensive than at present known for certain in the twilight zones of the caves. In particular, the very jagged, fretted surfaces of bedrock, boulders and old speleothem in many of the entrances might be so explained.

\section{ACKNOWLEDGEMENTS}

This work was carried out during the course of the Royal Geographical Society Mulu (Sarawak) Expedition, 1977-1978. The author was financed by a Natural Environment Research Council Research Studentship, held under the supervision of Dr. M.M. Sweeting. Thanks to all concerned!

\section{RIASSUNTO}

Un tipo particolare di fitocarsismo, condizionato dalla provenienza della luce, è stato trovato nella zona di ingresso di alcune grotte del Gunong Mulu National Park a Sarawak nella E. Malaysia.

Il fenomeno è dovuto all'azione di alghe (e/o muschi e licheni) sulle rocce carbonatiche. $\mathrm{La}$ superficie rocciosa soggetta a questa azione appare di colore verde chiaro con delle protuberanze di varia forma, descritte nel testo, ed orientate nella direzione di provenienza della luce. 


\section{REFERENCES}

BROOK, D.B. \& A.C. WALTHAM, 1978. Caves of Mulu. Royal Geographical Society, London.

CHADHA, S.K. 1976. Note on the evolution of phytokarst topography in the Great Limestone Formation of Jammu Province, J\&K State, India. Current Science (Bangalore) 45 (16):588-589.

EAVIS, A.J. 1981. Caves of Mulu '80. Royal Geographical Society, London. FOLK, R.L., H.H. ROBERTS \& C.H. MOORE, 1973. Black phytokarst from Hell, Cayman Islands, British West Indies. Geol. Soc. Am. Bull. 84:2351-2360.

LEY, R.G. 1980. The pinnacles of Gunung Api. Geogr. J. 146:14-21.

SWEETING, M.M., 1979. It always rains on Gunong Mulu. Geographical Magazine Jan. 51 (4):271-277.

SWEETING, M.M. 1979. Weathering and solution of the Melinau Limestones in the Gunong Mulu National Park, Sarawak, Malaysia, Ann. Soc. Geol. Belg. 102:53-57.

WALTHAM, A.C. \& D.B. BROOK. 1979. Caves in Mulu Mills. Geographical Magazine April 51 (7): 486-491. 